\title{
Reintroduction of the European mink Mustela Iutreola in Saarland, Germany. Preliminary data on the use of space and activity as revealed by radio-tracking and live-trapping
}

\author{
Elisabeth Peters ${ }^{1, *}$, Ilona Brinkmann ${ }^{1}$, Frauke Krüger ${ }^{2}$, Silke Zwirlein ${ }^{3}$, Ina Klaumann ${ }^{4}$ \\ ${ }^{1}$ Department of Ethology, University of Osnabrueck, Barbarastr 11, 49069 Osnabrück, Germany \\ ${ }^{2}$ Landschaftsökologie, Christian-Albrechts University of Kiel, Olshausenstr. 75, 24118 Kiel, Germany \\ ${ }^{3}$ Institute for Zoo and Wildlife Research, Evolutionary Ecology Research Group, Alfred-Kowalke-Str. 17, 10315 Berlin, Germany \\ ${ }^{4}$ Geographie/Geowissenschaften, University of Trier, Am Wissenschaftspark 25-27, 54296 Trier, Germany
}

\begin{abstract}
As an attempt to help conserve the endangered European mink Mustela lutreola (Linnaeus, 1761), a reintroduction program was started in a nature reserve in Saarland, Germany; the present study is part of this ongoing reintroduction project. Within the first $2 \mathrm{yr}$ period, $48\left(16 \mathrm{O}^{7}\right.$, 32 o) founder animals were reintroduced, out of a total of about 75 animals intended for release in the course of the $3 \mathrm{yr}$ project. Prior to reintroduction, the animals were acclimatized using soft-release pens where they were preconditioned with natural prey . A number of individuals $(n=18)$ were set free in groups of mating partners $\left(\wp^{\top} \sigma^{7}, \varphi^{7}\right)$ and in mother-offspring groups. Thirty-three European mink (14 $0^{t}, 19$ o) were fitted with intraperitonial transmitters and radio-tracked and surveyed via live-trapping. Animals were monitored from April 2006 to May 2008 to determine the distribution, size and temporal changes in home range. Released animals showed linear home ranges spreading along rivers and brooks. Home range sizes were $7.2 \mathrm{~km}$ (88 ha) for 1 adult male, $0.2-5.9 \mathrm{~km}$ (1-505 ha) for adult females, around 1.7-5.6 km (17-132 ha) for juvenile males and $9.2 \mathrm{~km} \mathrm{(778} \mathrm{ha)}$ for 1 juvenile female, respectively. The released adults showed inter-, but only few intra-, sexual home range overlaps. In contrast, juveniles did not show any home range overlaps. In winter, home range size decreased to a minimum of about $1 \mathrm{~km}$. Further, home range size for females decreased around parturition but increased successively at time of weaning. The activity pattern of released animals was highest at night (especially around dusk and dawn).
\end{abstract}

KEY WORDS: Release $\cdot$ Reintroduction $\cdot$ Home range $\cdot$ Intrasexual $\cdot$ Intersexual $\cdot$ Mustela lutreola Movement pattern

Resale or republication not permitted without written consent of the publisher

\section{INTRODUCTION}

Reintroduction as a conservation tool seeks to restore viable populations of native species within their historical range through the release of wild or captive-bred individuals following extirpation or extinction in the wild (IUCN 1998). However, reintroduction programs of endangered mammals, especially carnivores, are associated with high effort. Previous reviews have highlighted several factors that appear to contribute to their success or failure (Griffith et al. 1989, Stanley
Price 1991, Beck et al. 1994, Beck 1995, Wolf et al. 1996, Reading \& Clark 1997, Fischer \& Lindenmayer 2000, Breitenmoser et al. 2001, Seddon et al. 2007, Stamps \& Swaisgood 2007, Jule et al. 2008). The main biological and ecological factors that influence successful reintroductions include habitat suitability, natal habitat preference, long-term food availability, season of release, type of release (soft or hard) and source (wild-caught or captive-born) of released animals.

To help conserve the European mink and to gain insight into the biology of this species in situ, a reintro- 
duction program was implemented in Saarland, southwest Germany in 2006. Two experimental pilot studies preceded this program in northern Germany: (1) in experimental releases in northwestern Germany, individuals were first adapted to the conditions of the release site in soft-release pens which had been constructed on the banks of suitable streams (soft-release approach) (Schröpfer 2003); (2) at the same location, animals were also released in sibling groups (Schröpfer 2003). Further release attempts have been made on Hiiumaa Island, Estonia (2000 to 2004) (Maran 2004).

Macdonald et al. (2002) modelled the reintroduction of Mustela lutreola in Estonia using a preliminary population viability analysis to estimate the probability of successful establishment of the introduced population. They concluded that at least 30 to 40 founder animals are necessary to guarantee high genetic variability of a reintroduced population of $M$. lutreola originating from the eastern population, which has been verified as highly variable (Michaux et al. 2004, 2005). Based on the results of the aforementioned experimental reintroductions of $M$. lutreola, we released 48 animals over a 2 yr period in a nature reserve in Saarland as part of a larger release program (75 founder animals within a 3 yr period).

The European mink Mustela lutreola (Linnaeus, 1761) was once distributed throughout Europe. Habitat fragmentation and degradation, as well as interference by the invasive feral farm mink (American mink Neovison vison), are thought to be the main reasons for the massive population decline during the last century. Prior to this, habitat loss and overly extensive hunting were the main factors causing the local extinctions, but currently the widespread alien American mink is competing with $M$. lutreola for resources (Maran \& Henttonen 1995, Sidorovich et al. 1995, Maran et al. 1998, Sidorovich et al. 1999), and its larger size forces $M$. lutreola to withdraw to unsuitable habitats through aggressive encounters (socalled intraguild aggression; Sidorovich 2001). Existing populations of the European mink are restricted to southwestern France, northern Spain, Belarus, Russia and Romania (Maran \& Henttonen 1995), and may be further threatened by bottleneck effects due to their geographic isolation. Therefore, the European mink has been classified by the IUCN Red List as Endangered (Groombridge 1994). The European mink is a small semi-aquatic carnivore exhibiting some sexual size dimorphism: the average weight $( \pm \mathrm{SD})$ of captive-bred females and males ranges from 370 to $750 \mathrm{~g}$ (591 $\pm 87 \mathrm{~g}, \mathrm{n}=120)$ and from 460 to $1210 \mathrm{~g}$ (835 \pm $160 \mathrm{~g}, \mathrm{n}=86$ ), respectively (E. Peters unpubl. data, Sidorovich et al. 1999). Its main prey are mice, fish and crabs, and its life span is about 4 to 5 yr. In central Europe, females are in oestrus in spring, and after a
41 d gestation period 3 to 4 kits are born (Stubbe 1993). Mothers rear their kits up to the age of $11 \mathrm{wk}$; after that, they become very aggressive towards their offspring forcing their dispersal (so-called motheroffspring conflict).

It has been suggested that home range size of solitary male carnivores, at least during the mating season, is mainly determined by the dispersion of females, whereas female ranging patterns are determined by the dispersion of resources (Macdonald 1983, Mason \& Macdonald 1983, Erlinge \& Sandell 1986, Genovesi et al. 1997). Females are principally concerned with defending a home range that provides enough food in which to rear their offspring, whereas males maximize their reproductive success by encompassing as many mates in their home range as possible (Johnson et al. 2000) Thus males typically exhibit larger home ranges than females, with male ranges overlapping with those of females (Dunston 1993, Genovesi et al. 1997, Schröpfer et al. 1997). Consequently, home ranges of males are also ultimately determined, although indirectly, by food. This spacing pattern typically results in intrasexual territoriality.

Few radio-tracking data on the home range size of Mustela lutreola have been published: Palazón \& RuízOlmo (1998) found home range sizes of 6 to $8 \mathrm{~km}$ in wild-born males and 0.5 to $4.5 \mathrm{~km}$ in females. Garin et al. (2002a) published home range sizes of $11.1-18.8 \mathrm{~km}$ for males and $0.6-3.6 \mathrm{~km}$ for females. In France, Fournier et al. (2003) reported home range sizes of $9.4-16.2 \mathrm{~km}$ for wild-born males and $2.5-10.1 \mathrm{~km}$ for females, and in Estonia, reintroduced males and females exhibited home ranges of $2.7-3.2 \mathrm{~km}$ and 1.8-4.6 km, respectively (Macdonald et al. 2002). In all studies, home ranges of males were significant larger than home ranges of females (Palazón \& Ruíz-Olmo 1998, Garin et al. 2002a, Macdonald et al. 2002, Fournier et al. 2003). Garin et al. (2002a) found at least 3 females within the home ranges of 3 tracked males, and Macdonald et al. (2002) found a male's home range overlapping with those of 2 females. In the breeding season, these home range overlaps might exist for mating purposes; however, home ranges of male weasels Mustela nivalis and Neovison vison all contain at least 2 females even in the non-breeding season (Gerell 1970, Birks \& Linn 1982, Erlinge \& Sandell 1986, Dunston 1993). As these home range overlaps are most likely not for mating purposes, they may indicate defense of future potential mates during this period or protection of offspring (Schröpfer et al. 1997). Intersexual home range overlaps of $M$. lutreola in the non-breeding season have not yet been documented, although mating partners can be kept together in semi-natural enclosures year-round without aggressive encounters. To verify this idea in the 
wild, in the present study mating partners were released together, and migration and home range formation was observed.

Sandell (1989) suggested that if males are territorial, their home range size should not change seasonally. However, seasonal variation in male home range size has been documented for Mustela lutreola (Garin et al. 2002a) and the European pine marten Martes martes (Schröpfer et al. 1997). In contrast, changes in the home range size of females have not been documented. Females may adapt their home range to their reproductive stage - from pre- to postpartum to the weaning period. These changes in home range may be mirrored by their mating partners.

After experiencing mother-offspring conflict, juveniles may disperse to new territories. On the other hand, mothers may disperse and abandon their home ranges to their offspring. Experimental research on the social behavior of European mink sibling groups kept in seminatural enclosures found a predominantly socio-positive behavior between sibling partners up to the age of 5 to $6 \mathrm{mo}$, suggesting a migration to new territories in groups (E. Peters \& I. Brinkmann unpubl. data). To test this hypothesis, mother-offspring groups were released in the present study, and migration was observed.
Here we describe the spatial distribution of 48 releases of European mink. The aim of the present study was to gain preliminary insight into the social structure of a reintroduced population of European mink. Therefore, we determined migration and establishment of home ranges as well as home range sizes in comparison to those of natural populations. Data on post-release survival and site fidelity will be published elsewhere.

\section{MATERIALS AND METHODS}

Study area. The reintroduction was conducted in the nature reserve 'Täler der Ill und ihre Nebenbäche' in Saarland, Germany ( 49.0 to $50.0^{\circ} \mathrm{N}, 7.0^{\circ} \mathrm{E}$ ). The core area is a $125 \mathrm{~km}^{2}$ nature reserve located in the middle of Saarland between the towns of Lebach and Ottweiler encompassing 140 river $\mathrm{km}$. The River Ill has the typical characteristics of a low mountain stream: the river has its source at $395 \mathrm{~m}$ above sea level and falls into the River Theel after about $30 \mathrm{~km}$ at $220 \mathrm{~m}$ above sea level. The largest water course close to it is named Alsbach, flowing into the area from the north (Fig. 1).

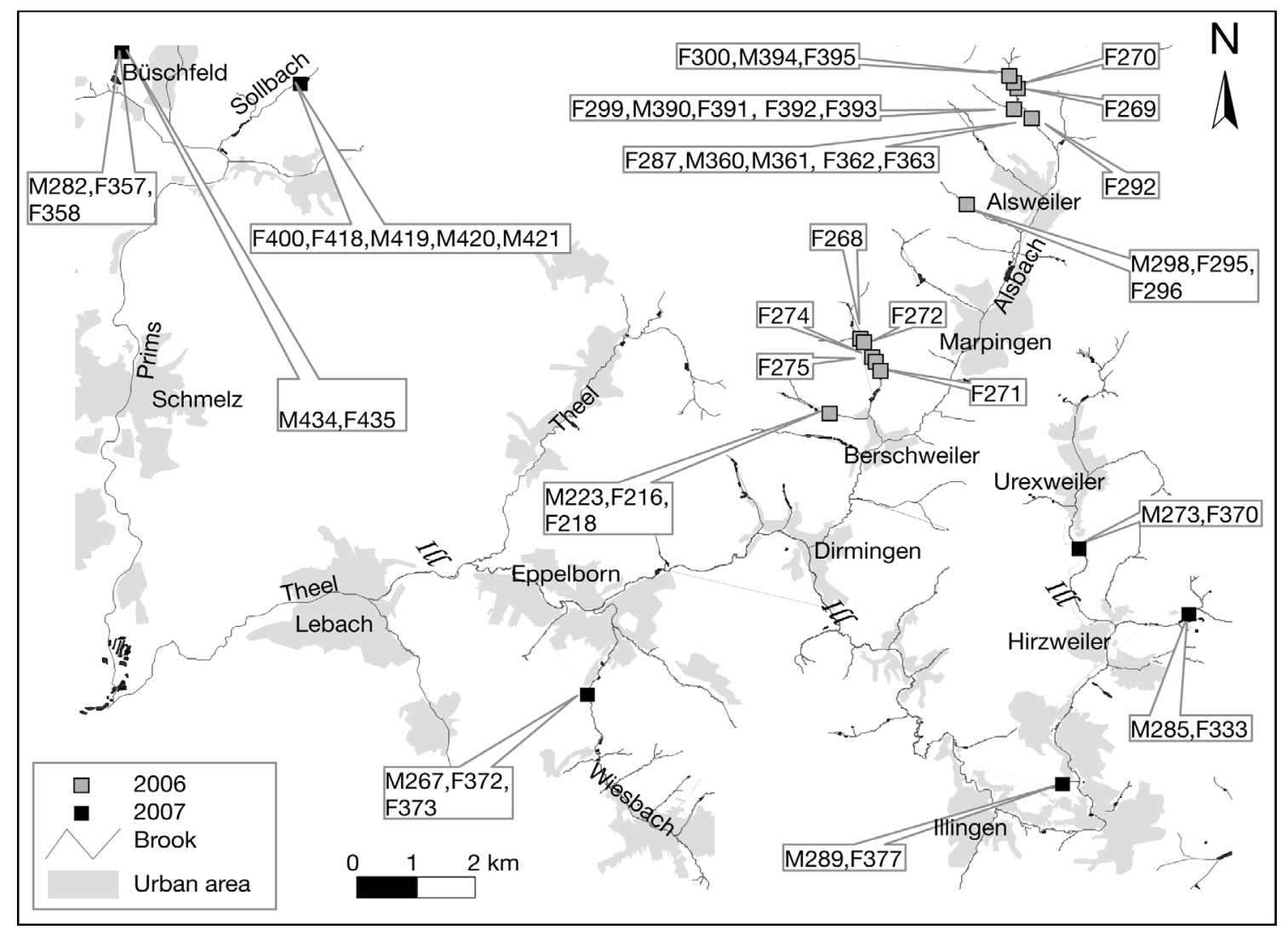

Fig. 1. Location of soft-release pens (M: male; F: female) at the release site $\left(49.0\right.$ to $\left.50.0^{\circ} \mathrm{N}, 7^{\circ} \mathrm{E}\right)$ over the 2 yr reintroduction period (April 2006 to May 2008) 
Animal preparation. Animals for reintroduction were born in captivity at the breeding station EuroNerz e.V. Since 1998, this institution has been part of a European breeding program (Foundation lutreola, Estonia) started in 1992 aimed at rescuing — at least ex situ-Mustela lutreola. Starting with 6 founders originating from a breeding stock in Novosibirsk (Russia), more than 500 animals have been bred in the controlled breeding environment within $10 \mathrm{yr}$.

The present study is part of an ongoing reintroduction project. During a 2 yr study period, 48 animals were released. Before release, adults were kept in large enclosures with natural interior (i.e. enclosures adapted from natural environment and including water basins, small trees, branches, stones and several hiding places), because animals in large enclosures are typically very shy, behaving in the same manner as animals in the wild (Maran 2004).

In both years, adult males were released in April or May; females were either released in April or May in groups with their mating partners $\left(\% \circ 0^{7}, \phi 0^{7}\right)$, or in August in mother-offspring groups (Table 1). Five pregnant females delivered their kits in soft-release pens before they were released with their offspring. The other pregnant females $(\mathrm{N}=19)$ were released after a $2 \mathrm{wk}$ acclimatization period within their individual soft release pens. Adult males $(\mathrm{N}=7)$ were released only with their mating partners, and therefore verified as competent breeders prior to release.

Surgery and implantation. For individual recognition, all released animals were microchipped $(2.12 \times 11.5 \mathrm{~mm}$, Trovan ${ }^{\circledR}$ ID100) subcutaneously between the scapulae at the age of $6 \mathrm{wk}$. Microchipping was performed without anesthesia. Additionally, 33 animals (adults: 6 o", 12 o; juveniles: 8 व, 7 o) were fitted with intraperitoneal transmitters (Microtes Wildlife Engineering) during a 30 min surgery performed by a veterinary surgeon under a license issued by the Bezirksregierung Weser-Ems.

Because of the lack of differentiation between head and neck circumference, as well as the semi-aquatic and frequently subterranean habitats of Mustela lutreola, the use of conventional radio-collar transmitters may be impracticable. Further, in other reintroduction

Table 1. Mustela lutreola. Subgroups of European mink released during the $2 \mathrm{yr}$ reintroduction period (April 2006 to May 2008)

\begin{tabular}{|c|c|c|c|c|c|}
\hline \multirow{2}{*}{$\begin{array}{l}\text { Release } \\
\text { category }\end{array}$} & \multicolumn{3}{|c|}{ — No. of groups } & \multirow[t]{2}{*}{ q } & \multirow{2}{*}{$\begin{array}{c}\text { Total no. } \\
\text { of } \\
\text { animals }\end{array}$} \\
\hline & $\sigma^{7} \circ$ 우 & $\sigma^{\prime \prime}$ & $\begin{array}{l}\text { Mother- } \\
\text { offspring }\end{array}$ & & \\
\hline Year 1 & 2 & 0 & 3 & 8 & 27 \\
\hline Year 2 & 2 & 3 & 2 & 0 & 21 \\
\hline No. of animals & 12 & 6 & 22 & 8 & 48 \\
\hline
\end{tabular}

projects radio-collars resulted in appalling wound problems which caused the death of some animals (Birks \& Linn 1982, Eagle et al. 1984, Zschille et al. 2008, R. Schröpfer, T. Maran \& V. E. Sidorovich pers. comm.). In contrast, implants have been used successfully in M. lutreola (Fournier et al. 2001, Mañas pers. comm.) as well as in other species (Eagle et al. 1984, Skirnisson \& Feddersen 1984, Zschille et al. 2008). Free-ranging $M$. lutreola fitted with implants reproduced without problems, although in up to 3 surgeries, transmitters were exchanged (S. Mañas pers. comm.).

It could be argued that the use of flank wall-attached transmitters is better than the use of the free-floating type, because of occasional cases in which transmitters have migrated (Broadhurst et al. 1996, Hawkins 2004). However, not enough is known about transmitter fixation methods, and particularly not in animals. We would recommend research under laboratory conditions to compare both methods. After intensive literature review and discussions with experienced wildlife biologists and veterinarians, we decided to use the intraperitoneal implantation method. Thus, implants were placed free-floating into the peritoneal cavity without anchoring to the flank wall.

Transmitters were sterilized with ethylenoxid gas at $37^{\circ} \mathrm{C}$. Animals were immobilized with $100 \mu \mathrm{g}$ per kg animal weight Medetomidin (Domitor ${ }^{\circledR}$ ) and $5 \mathrm{mg}$ per $\mathrm{kg}$ animal weight Ketaminhydrochlorid (Ketamin ${ }^{\circledR}$ ) given intramuscularly. This combination was used successfully for anaesthetization in Mustela lutreola in Spain (S. Mañas pers. comm.) as well as in the black-footed ferret M. nigripes (Kreeger et al. 1998). During surgery, animals were kept in narcosis by a mixture of Isofluoran ${ }^{\circledR}$ and oxygen administered through a mask. An intramuscular injection of Atipamezol (Antisedan ${ }^{\circledR}$ ) and the supply of pure oxygen shortened the recovery phase and the animals awoke immediately after surgery. Further, animals were supplied subcutaneously with the antibiotic Enrofloxacin $\left(7.5 \mathrm{mg}\right.$ per $\mathrm{kg}$ animal weight, Baytril ${ }^{\circledR}$ $2.5 \%)$ and the non-steroidal antiphlogisticum Meloxicam $\left(0.25 \mathrm{mg}\right.$ per $\mathrm{kg}$ animal weight, Metacam ${ }^{\circledR} 5 \mathrm{mg}$ $\mathrm{ml}^{-1}$ ). Post-surgery, animals received further dosages of Enrofloxancin orally with their food (further details on the surgery will be published elsewhere).

Transmitters for adults (Microtes IM 03) were $51.6 \times$ $16.6 \mathrm{~mm}$, weighed $17 \mathrm{~g}$ (i.e. $<3 \%$ of animal mass) and had an expected life-span of 6 to 18 mo. Transmitters for juveniles (Microtes IM 02) were $31.6 \times 11.6 \mathrm{~mm}$, weighed $6 \mathrm{~g}$ (i.e. $<1.7 \%$ of animal mass) and had an expected life-span of $5 \mathrm{mo}$. The frequency of both transmitters was $36.15 \mathrm{MHZ}$, which ensured $500 \mathrm{~m}$ of tracking distance.

After being fitted with transmitters, animals were held in quarantine for at least $3 \mathrm{~d}$ to control their wounds and monitor the healing process. Further, ani- 
mal behavior was monitored for any implant effects, although impairments typically appear when implant weight exceeds 4 to $5 \%$ of the animal's body mass (Macdonald 1978, Kenward 2001).

Soft release methods. For at least 2 wk prior to release, the animals were acclimatized at the release site in softrelease pens (Fig. 1) measuring $5 \times 2 \mathrm{~m}$. All animals were able to practice their hunting skills on natural prey species (e.g. Apodemus sylvaticus, Microtus arvalis, $M$. agrestis, Clethrionomys glareolus, Scardinus erythophthalmus, Astacus astacus, Orconectes limosus). Pens were placed in different orders. Pregnant females (F268, F269, F270, F271, F272, F274, F275 and F292) were acclimatized in solitary pens spaced at least $500 \mathrm{~m}$ apart. Mating pairs (M273-F370, M289-F377, M285F333) were acclimatized together within solitary pens (Fig. 1, Tables 1 \& 2), and 4 groups each of 2 pregnant sisters and their mating partner (M223-F216- F218, M267-F372-F373, M282-F357- F358 and M298F295-F296) were acclimatized in solitary pens with a maximal distance between pens of 1 to $2 \mathrm{~m}$ facilitating visual and olfactory contact. Five pregnant females (F287, F299, F300, F399 and F400) delivered and raised their kits in separate pens spaced 500 to $5000 \mathrm{~m}$ apart.

Radio-tracking and live-trapping. Radio-tracking and live-trapping occurred from April 2006 to May 2008 to determine the distribution, size and temporal changes in home range of released animals. Animals with implanted transmitters were radio-tracked twice daily. For radio-tracking, fixes were taken on foot or by car in the surveyed area, using triangulation to home in on the animal (White \& Garrott 1990). As a compromise between autocorrelation of the fixes and accuracy of estimation, localizations were at least $30 \mathrm{~min}$ apart. At least 4 fixes of each animal were taken each day.

The remaining animals not equipped with transmitters (adults: $10^{7}, 12$ o; juveniles: $1 \sigma^{7}, 1$ o) were tracked by live-trapping under the license issued by the Saarland Ministry of Environment. To prevent the death of the offspring, live-trapping was not performed until pregnant females had delivered and raised their kits. Thus trapping began when juveniles were $4 \mathrm{wk}$ old. Traps were checked every $4 \mathrm{~h}$ during summer, and twice a day in autumn and winter. Animals were trapped in single-entry wood traps $(25 \times 25 \times 45 \mathrm{~cm})$, placed $200 \mathrm{~m}$ apart in stream banks. This setup was successfully used in Spain for catching wild European mink (S. Palazón pers. comm.). Day-old chicks, chicken eggs, and oil of sardines were used as bait. Caught animals were weighed and their microchips scanned.

Analyses of radio-tracking data. GIS modeling is an appropriate method to analyze movement and home ranges of mustelids, especially where species are bound to specific habitat components (Gough \& Rushton 2000). The home range estimation was conducted using ArcView 3.2 and the related extensions Animal Movement and Spatial Analyst (ESRI).

For analyzing movement and habitat preference, home ranges were estimated with kernel density estimation (50 and $95 \%$ kernels). The smoothing factor $(\mathrm{H})$ was selected with least squares cross validation. Additionally, $100 \%$ minimum convex polygons were estimated, and site fidelity was appraised with ArcView. Animals were defined as either transient or resident, determined by their movement pattern: transient animals moved randomly in the surveyed area, whereas residents seem to follow non-random movement patterns. Activity patterns were calculated as the proportion of active radio fixes per hour.

\section{RESULTS}

Forty-eight captive bred European mink were released between May 2006 and August 2007. Details on the individuals, including date of release, time under observation, fate and home range size are shown in Table 2. Data on the post-release survival and site fidelity will be published elsewhere (E. Peters et al. unpubl. data).

Thirty-three individuals fitted with implanted radiotransmitters were radio-tracked and monitored for 1 to $342 \mathrm{~d}$ (mean \pm SD: $77 \pm 98$ d) (Table 2). Fifteen juveniles originating from 4 litters were radio-tracked and monitored for 1 to 264 d, Eighteen adults were tracked for 2 to $342 \mathrm{~d}$, indicating that the majority were able to survive independently. Of all animals released, 29\% (n = 14) died after 12 mo of observation (E. Peters et al. unpubl. data).

For 13 ind. the quantity of data allowed a calculation of home ranges. The movement of these reintroduced animals along the rivers (Fig. 2) resulted in linear home ranges. The home range of adult male M223 comprised $7.2 \mathrm{~km}$ of river length (88 ha, Table 2). Juvenile males established home ranges of 17 to 274 ha, sometimes bigger than the home range of the adult male, although the river length (1.7 to $5.6 \mathrm{~km})$ patrolled was somewhat shorter (Table 2). Adult females typically exploited a much smaller area, with home ranges comprising 0.2 to $5.9 \mathrm{~km}$ of river length (4 to 505 ha, Table 2); in contrast, 1 juvenile female (F362) established a home range of $9.2 \mathrm{~km}$ (778 ha).

\section{Intra- and intersexual home range overlap}

After release, intrasexual home range overlaps of 3 adult females were observed for a $5 \mathrm{~d}$ period (Fig. 3a). Afterwards, 2 of these females (F271 and F272) disappeared from this area. In adult males, neither initial nor 
Table 2. Mustela lutreola. Date of release, age, weight, implant status, time under observation, fate and home range size (km river length) of European mink released during the present study $(n=48)$. D: dead; LS: lost signal; FU: fate unknown; UO: under observation. Blanks indicate no data available (weight column), and no home range established (home range columns)

\begin{tabular}{|c|c|c|c|c|c|c|c|c|c|c|}
\hline & $\begin{array}{c}\text { Specimen } \\
\text { no. }\end{array}$ & $\begin{array}{c}\text { Release } \\
\text { date } \\
\mathrm{dd} / \mathrm{mm} / \mathrm{yy}\end{array}$ & $\begin{array}{r}\text { Age } \\
\text { (d) }\end{array}$ & $\begin{array}{l}\text { Weight } \\
\text { (g) }\end{array}$ & Implant & $\begin{array}{l}\text { Time under } \\
\text { observation } \\
\text { (d) }\end{array}$ & $\begin{array}{c}\text { No. of } \\
\text { locations }\end{array}$ & Fate & $\begin{array}{c}\text { Home } \\
\mathrm{km}\end{array}$ & $\begin{array}{c}\text { range size } \\
\text { ha (95\% } \\
\text { kernel) }\end{array}$ \\
\hline \multicolumn{11}{|c|}{ Mother-offspring groups } \\
\hline Mother & F287 & $11 / 08 / 06$ & 453 & 373 & + & 3 & 21 & $\mathrm{D}$ & & \\
\hline Kit & M360 & $11 / 08 / 06$ & 82 & 426 & + & 181 & 113 & LS & 5.6 & 132 \\
\hline Kit & M361 & 11/08/06 & 82 & 436 & + & 6 & 26 & LS & & \\
\hline Kit & F362 & 11/08/06 & 82 & 353 & + & 158 & 74 & LS & 9.2 & 778 \\
\hline Kit & F363 & 11/08/06 & 82 & 357 & + & 42 & 34 & LS & & \\
\hline Mother & F299 & 21/08/06 & 416 & 477 & + & 11 & 127 & LS & & \\
\hline Kit & M390 & $21 / 08 / 06$ & 76 & 490 & + & 198 & 208 & LS & 5.0 & 274 \\
\hline Kit & F391 & $21 / 08 / 06$ & 76 & 442 & + & 7 & 45 & $\mathrm{D}$ & & \\
\hline Kit & F392 & $21 / 08 / 06$ & 76 & 401 & + & 19 & 57 & $\mathrm{D}$ & & \\
\hline Kit & F393 & $21 / 08 / 06$ & 76 & 418 & + & 6 & 38 & LS & & \\
\hline Mother & F400 & $31 / 07 / 07$ & 438 & 548 & + & 77 & 469 & LS & 5.9 & 505 \\
\hline Kit & F418 & $31 / 07 / 07$ & 65 & 300 & + & 14 & 228 & $\mathrm{D}$ & & \\
\hline Kit & M419 & $31 / 07 / 07$ & 65 & 308 & + & 1 & 20 & $\mathrm{D}$ & & \\
\hline Kit & M420 & $31 / 07 / 07$ & 65 & 340 & + & 24 & 269 & LS & & \\
\hline Kit & M421 & $31 / 07 / 07$ & 65 & 354 & + & 126 & 459 & LS & 3.7 & 139 \\
\hline Mother & F399 & 08/08/07 & 446 & 550 & + & 273 & 609 & UO & 1.7 & 12 \\
\hline Kit & M433 & 08/08/07 & 67 & 386 & + & 264 & 538 & LS & 1.7 & 17 \\
\hline Kit & M434 & 08/08/07 & 67 & 398 & + & 20 & 144 & $\mathrm{D}$ & & \\
\hline Kit & F435 & 08/08/07 & 67 & 310 & + & 14 & 104 & LS & & \\
\hline Mother & F300 & $25 / 07 / 06$ & 389 & & - & 10 & 2 & FU & & \\
\hline Kit & M394 & $25 / 07 / 06$ & 60 & & - & 0 & 0 & FU & & \\
\hline Kit & F395 & $25 / 07 / 06$ & 60 & & - & 0 & 0 & FU & & \\
\hline \multicolumn{11}{|c|}{ Adult females } \\
\hline & F216 & 06/05/06 & 675 & 633 & + & 102 & 65 & D & 3.5 & 76 \\
\hline & F218 & 06/05/06 & 675 & 595 & + & 279 & 146 & LS & 1.5 & 4 \\
\hline & F268 & 06/05/06 & 318 & & - & 0 & 0 & FU & & \\
\hline & F269 & 30/05/06 & 342 & & - & 0 & 0 & FU & & \\
\hline & F270 & $25 / 06 / 06$ & 368 & & - & 0 & 0 & FU & & \\
\hline & F271 & 06/05/06 & 318 & 510 & + & 25 & 25 & $\mathrm{D}$ & 2.8 & 187 \\
\hline & F272 & 06/05/06 & 318 & 490 & + & 43 & 35 & $\mathrm{D}$ & 0.2 & 1 \\
\hline & F274 & 06/05/06 & 341 & & - & 80 & 4 & FU & & \\
\hline & F275 & 06/05/06 & 341 & & - & 0 & 0 & FU & & \\
\hline & F292 & 16/05/06 & 334 & & - & 0 & 0 & FU & & \\
\hline & F295 & $24 / 05 / 06$ & 365 & & - & 0 & 0 & FU & & \\
\hline & F296 & $24 / 05 / 06$ & 365 & & - & 283 & 8 & LS & & \\
\hline & F333 & $24 / 04 / 07$ & 330 & & - & 0 & 0 & FU & & \\
\hline & F370 & 03/04/07 & 315 & 572 & + & 342 & 679 & UO & 4.3 & 112 \\
\hline & F372 & $21 / 05 / 07$ & 363 & 598 & + & 123 & 478 & LS & & \\
\hline & F373 & $21 / 05 / 07$ & 363 & 671 & + & 2 & 63 & $\mathrm{D}$ & & \\
\hline & F357 & $14 / 05 / 07$ & 359 & 743 & - & 55 & 2 & FU & & \\
\hline & F358 & $14 / 05 / 07$ & 359 & 600 & + & 53 & 268 & $\mathrm{D}$ & & \\
\hline & F377 & $12 / 04 / 07$ & 315 & 510 & - & 0 & 0 & $\mathrm{FU}$ & & \\
\hline \multicolumn{11}{|c|}{ Adult males } \\
\hline & M223 & 06/05/06 & 720 & 910 & + & 86 & 134 & $\mathrm{D}$ & 7.2 & 88 \\
\hline & M267 & $21 / 05 / 07$ & 698 & 923 & + & 2 & 51 & D & & \\
\hline & M273 & 03/04/07 & 673 & 937 & + & 0 & 10 & LS & & \\
\hline & M282 & 14/05/07 & 735 & 904 & + & 16 & 182 & D & & \\
\hline & M285 & $24 / 04 / 07$ & 709 & 790 & + & 3 & 95 & LS & & \\
\hline & M289 & $12 / 04 / 07$ & 665 & & + & 6 & 39 & LS & & \\
\hline & M298 & $24 / 05 / 06$ & 327 & & - & 0 & 0 & FU & & \\
\hline
\end{tabular}

persistent intrasexual home range overlaps were observed. Adult male M298, released with its mating partners F295 and F296 was not tracked within the home range of M223. Similarly, juvenile males (M360, M390, M421 and M433), released in August with their litter mates, were not tracked in each others' home ranges.

Intersexual home range overlap was observed between male M223 and his 2 mating partners, females F216 and F218, during the first 2 wk after release (Fig. 3b). Subsequently, F216 changed position and 

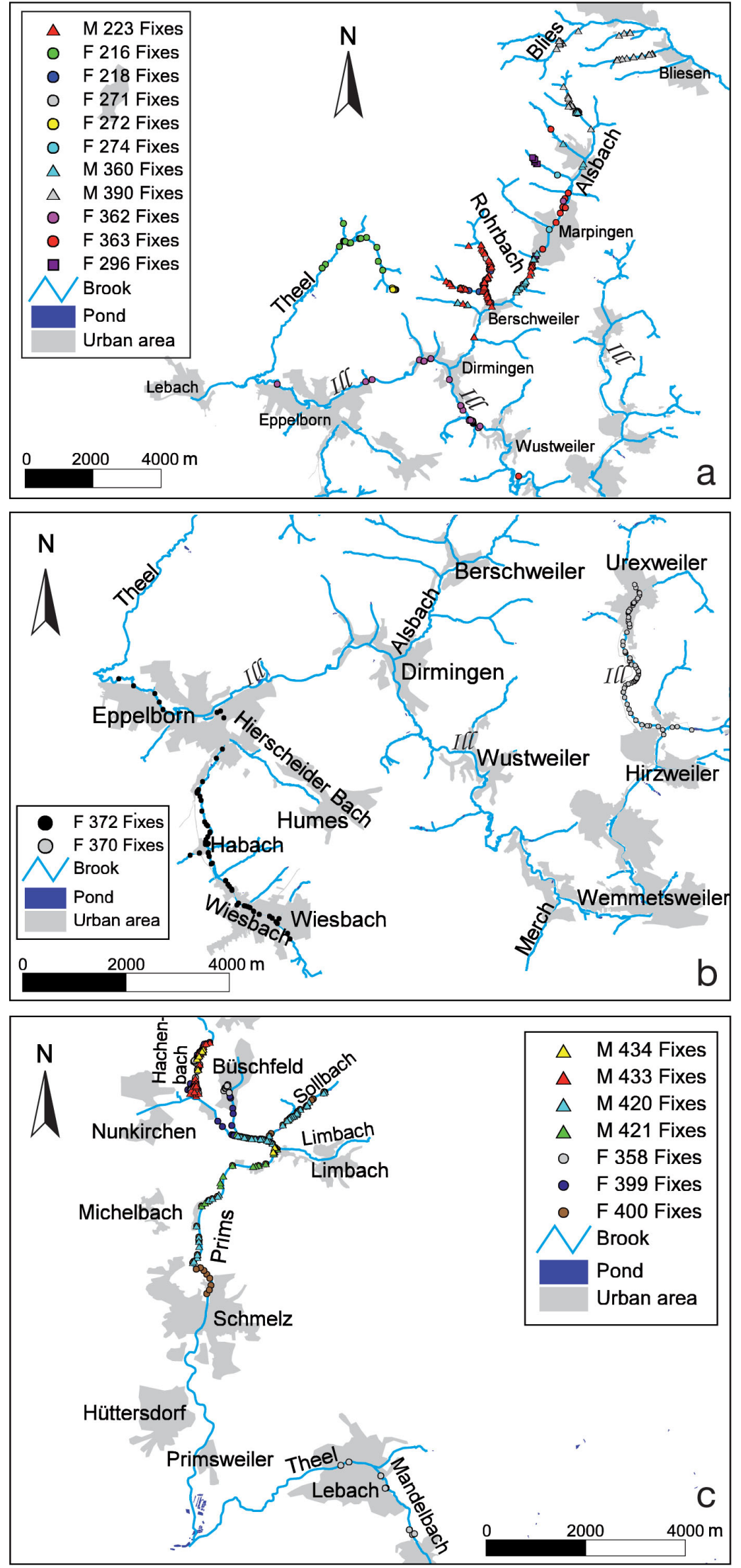

moved to a neighboring brook system (Fig. 3c), but the home ranges of M223 and F218 showed high concordance during the time of survey (86 d) (Fig. 3d).

For juveniles released in late summer, neither intra- nor intersexual overlapping of home ranges of males (M421-M433, M360-M390) or females was found (Fig. 4e,f). However, home range overlaps of mothers and sons (Fig. 5) were observed during the survey period (F399-M433, F400-M421).

\section{Home range formation}

Home range formation is shown for the adult female F216 (Fig. 3c), as well as for 1 juvenile female F362 and 3 juvenile males (Fig. 4). Female F216 exploited a total of $4250 \mathrm{~m}$ (538 ha) of brooks, divided into 2 distinctive areas. The release area was used for only $10 \mathrm{~d}$ after release (697 $\mathrm{m}$ river length, 2891 ha). Subsequently, F216 left this area $4 \mathrm{~d}$ before estimated date of parturition and established a permanent home range $(3553 \mathrm{~m}$ river length, $75648 \mathrm{ha}$ ) $4 \mathrm{~km}$ to the northwest (Fig. 3c); no further exploitation of the prior home range was observed.

Juveniles stayed at the release site for only a short period ( 2 to $14 \mathrm{~d}$ ). They left the soft-release pen and moved continuously along the brook system, later accelerating their migration speed until the first month after release (E. Peters et al. unpubl. data). Litter mates male M360 and female F362 emigrated together from the soft-release pen to the southwest (Fig. 4a,b) and occupied new riverine habitats $2.39 \mathrm{~km}$ apart from each other (Fig. 4f). Their home ranges were established 5.4 and $9.6 \mathrm{~km}$ from the soft-release pen after 27 and $41 \mathrm{~d}$,

Fig. 2. Mustela lutreola. Dispersal of European mink released at the brooks of the (a) Alsbach (F216: $\mathrm{n}=65, \mathrm{~F} 218: \mathrm{n}=146, \mathrm{M} 223: \mathrm{n}$ $=134 ;$ F271: $\mathrm{n}=25 ;$ F272: $\mathrm{n}=35 ; \mathrm{F} 274: \mathrm{n}=4$; F296: $\mathrm{n}=8$; M360: $\mathrm{n}=113 ; \mathrm{F} 362: \mathrm{n}=74 ;$ F363: $\mathrm{n}=34$; M390 $\mathrm{n}=208$ ), (b) River Ill (F370: $\mathrm{n}=$ 679, F372: $\mathrm{n}=478$ ) and (c) River Prims (F358: $\mathrm{n}=268$, F399: $\mathrm{n}=609, \mathrm{~F} 400: \mathrm{n}=469$, M420: $\mathrm{n}$ = 269, M421: $\mathrm{n}=459$, M433: $\mathrm{n}=538, M 434: \mathrm{n}$ =144). Animals were under observation for at least 20 d. n: Number of fixes (radiolocation and/or trapping observations) 

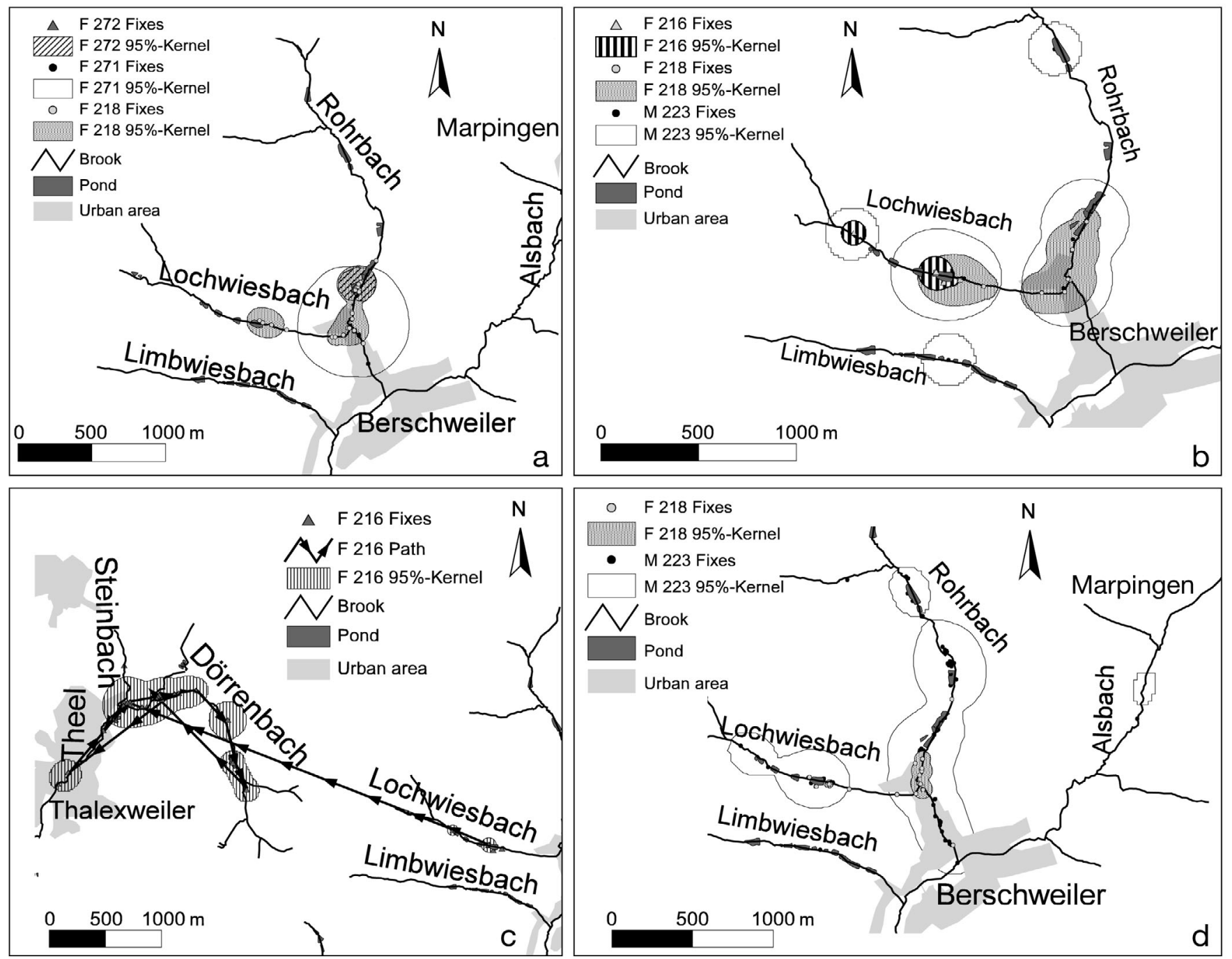

Fig. 3. Mustela lutreola. Home range overlaps of (a) 3 adult females (F271, $\mathrm{n}=18$; F272, $\mathrm{n}=20$; and F218, $\mathrm{n}=18$ ) during the first $5 \mathrm{~d}$ after their release, and (b) 2 sisters, F216 $(n=24)$ and F218 $(n=31)$, and their mating partner M223 (n = 26) 2 wk after release. Home range formation of (c) F216 ( $=65)$ and $(d)$ F218 $(n=145)$ and its mate M223 ( $=134)$ during their survey $(86$ d)

respectively. From mid-August 2006 to March 2007, M360 occupied part of the Alsbach brook, where adult male M223 lived until its death at the end of July 2006 (Fig. 6). M223 used a home range of $7.2 \mathrm{~km}(88 \mathrm{ha})$ and M360 of $5.6 \mathrm{~km} \mathrm{(132} \mathrm{ha);} \mathrm{in} \mathrm{fact,} \mathrm{their} \mathrm{overall} \mathrm{home}$ ranges overlapped spatially by as much as $4.1 \mathrm{~km}$ (22.4 ha, $25.4 \%$ ), though not temporally.

Male M390 emigrated $26 \mathrm{~d}$ after release to the northeast into a new brook system $3.5 \mathrm{~km}$ from its release site (Fig. 4c). This male was forced to cross unsuitable habitats to get to its new habitat of $5 \mathrm{~km}$ length (274 ha). Male M421 migrated with his mother F400 $5.1 \mathrm{~km}$ away from their release site into the Prims River (Fig. 4d). Afterwards, M421 established a home range of $139 \mathrm{ha}(3.7 \mathrm{~km})$ at the Prims River located within the home range ( $505 \mathrm{ha}, 5.9 \mathrm{~km}$ ) of his mother. The overlap lasted until $77 \mathrm{~d}$ after their release (Fig. 5b), at which point, the signal of the mother was lost (Table 2).

Female F399 and her litter remained at their release site (Figs. 4e \& 5a). F399 and male offspring M433 were tracked in this region for 273 and $264 \mathrm{~d}$, respectively. Both individuals established overlapping home ranges of 12 and 17 ha $(1.7 \mathrm{~km})$, respectively (Table 2).

\section{Seasonal changes in home range size}

Home range size with respect to reproductive state

Home range sizes of 3 females (F216, F218 and F370) with kits varied during different periods of reproductive 

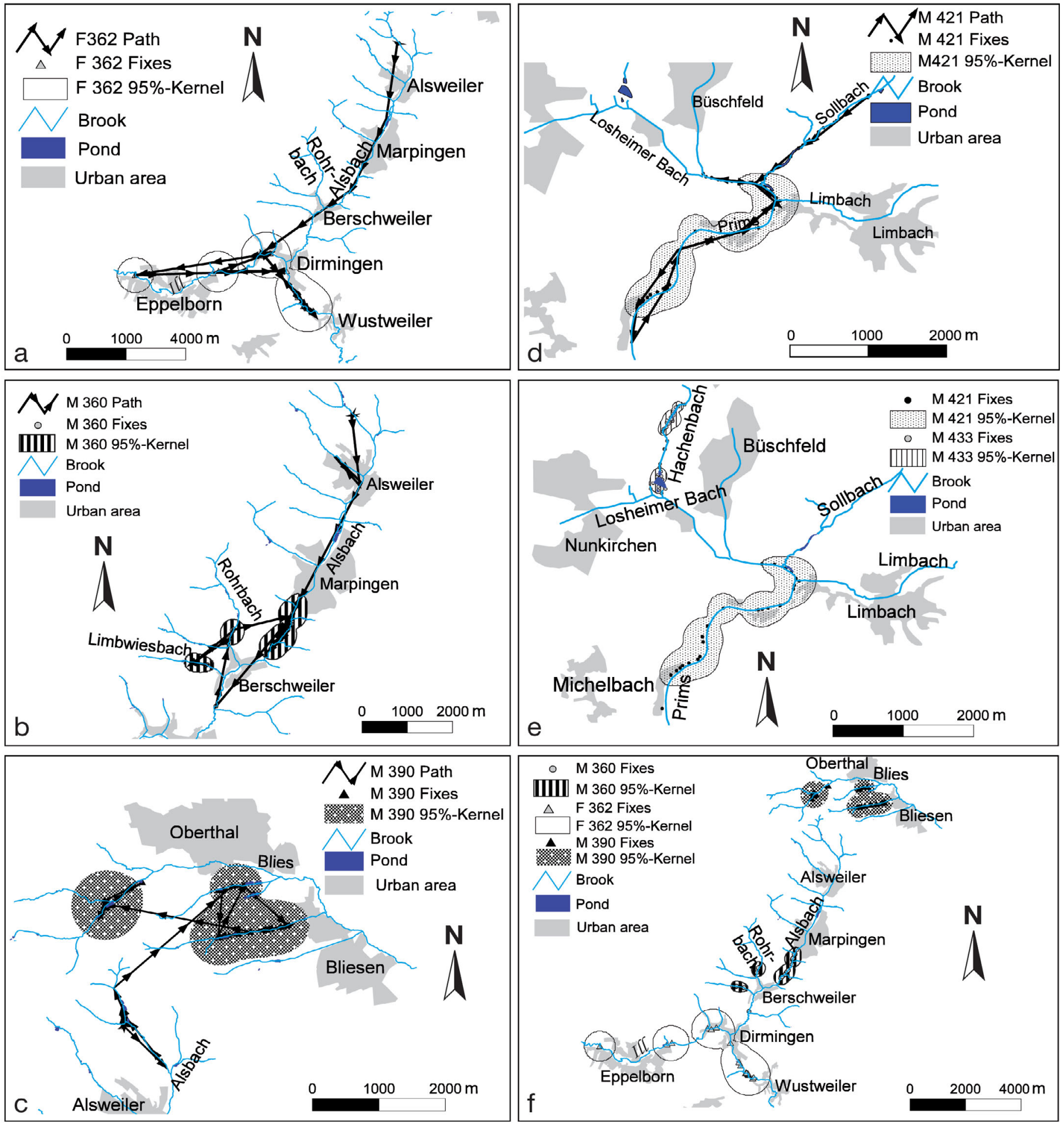

Fig. 4. Mustela lutreola. Home range formation of juveniles beginning 2 to $14 \mathrm{~d}$ after their release in summer. (a) F362 (n = 67), (b) M360 ( $\mathrm{n}=98),(\mathrm{c}) \mathrm{M} 390(\mathrm{n}=121)$ and $(\mathrm{d}) \mathrm{M} 421(\mathrm{n}=410)$. Winter home ranges established by (e) M421 ( $=211)$ and M433 ( $=504)$, and (f) F362 $(\mathrm{n}=42)$, M360 $(\mathrm{n}=74)$ and M390 $(\mathrm{n}=48)$

state (Fig. 7a-c). After release and prepartum, these females established home ranges of $2.4(0.5 \mathrm{~km}), 14.0$ $(1.7 \mathrm{~km})$ and 58.7 ha $(2.0 \mathrm{~km})$, respectively. Postpartum home ranges decreased to $0.3(0.2 \mathrm{~km})$ and 7.9 ha $(1.0 \mathrm{~km})$ for $\mathrm{F} 218$ and $\mathrm{F} 370$, respectively; in contrast, F216 increased her home range from 2.4 to 23.1 ha 


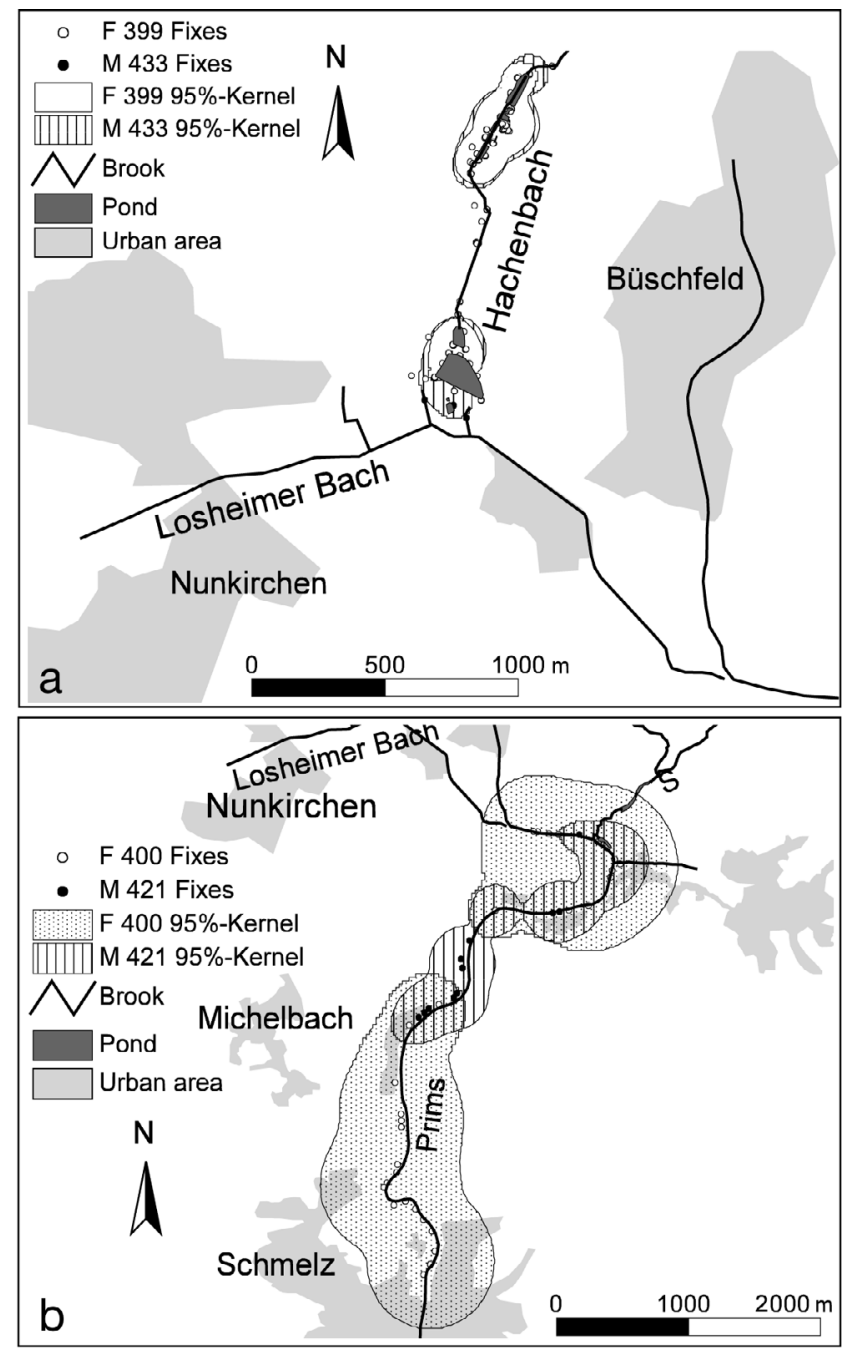

Fig. 5. Mustela lutreola. Home range overlaps of (a) mother F399 ( $\mathrm{n}=536)$ and son M433 $(\mathrm{n}=504)$ during time of survey $(264 \mathrm{~d})$ and $(\mathrm{b})$ mother F400 ( $\mathrm{n}=179)$ and son M421 $(\mathrm{n}=211)$ until $77 \mathrm{~d}$ after release

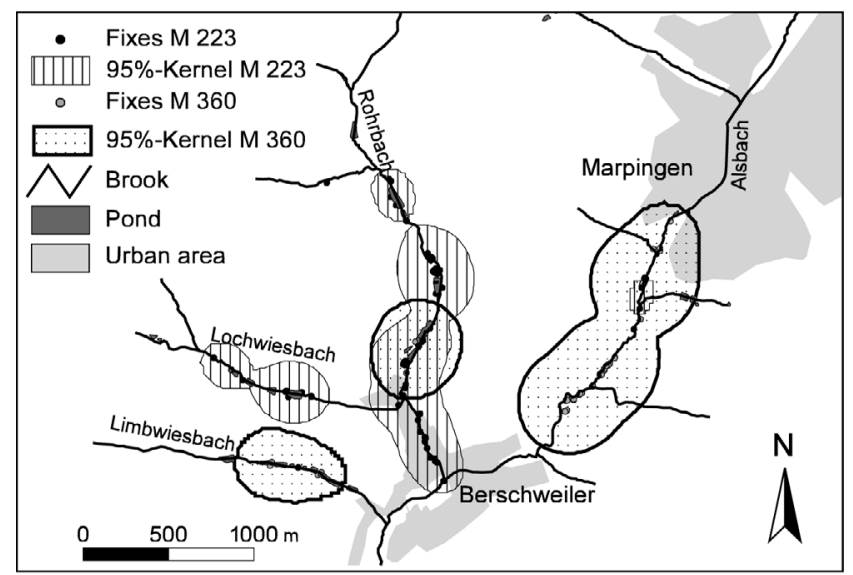

Fig. 6. Mustela lutreola. Occupation of home range by male M360 (n = 74) after the death of male M223 (n=133)
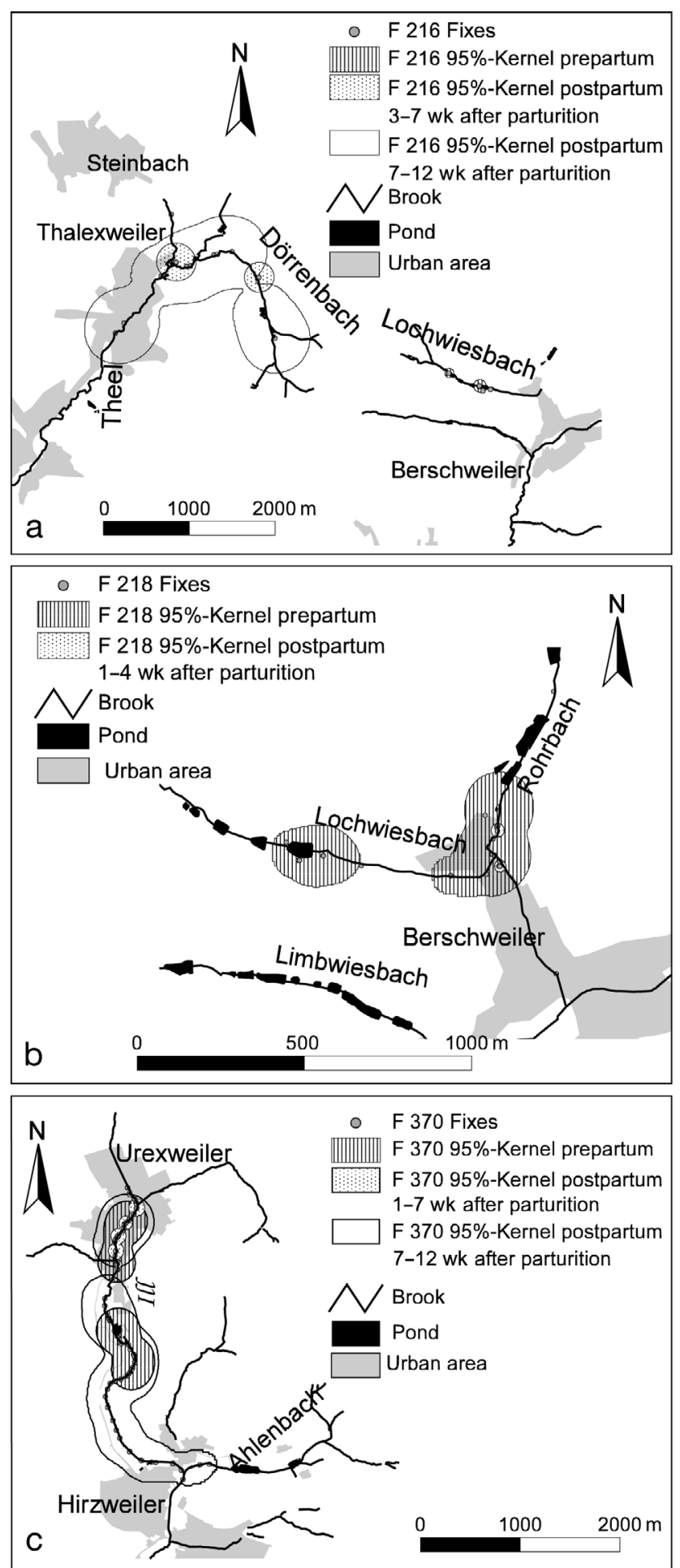

Fig. 7. Mustela lutreola. Home range size of females (F216, F218 and F370) guiding kits with respect to time before and after parturition. F216: prepartum $(\mathrm{n}=24)$, postpartum 3 to $7 \mathrm{wk}$ after parturition $(\mathrm{n}=27)$, postpartum 7 to $12 \mathrm{wk}$ after parturition $(\mathrm{n}=14)$; F218: prepartum $(\mathrm{n}=50)$, postpartum 1 to $4 \mathrm{wk}$ after parturition $(\mathrm{n}=95)$; and F370: prepartum $(\mathrm{n}=106)$, postpartum 1 to 7 wk parturition $(\mathrm{n}=205)$ and 7 to 12 wk after parturition $(\mathrm{n}=191)$ 


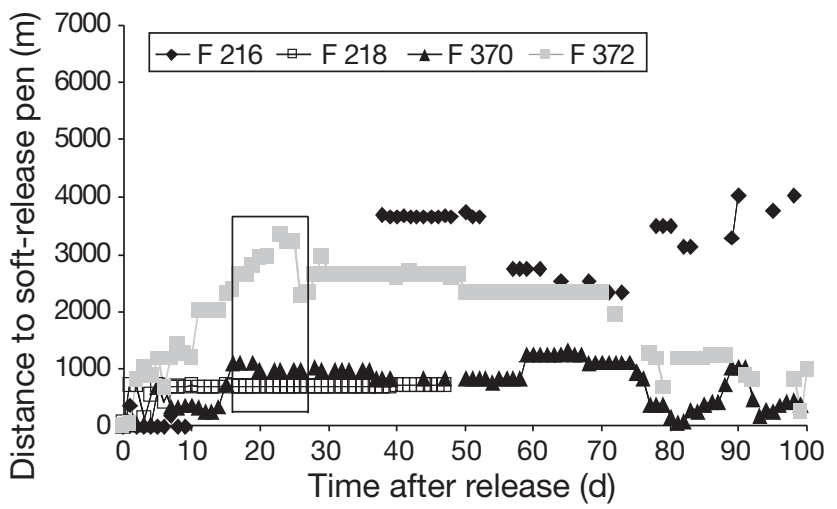

Fig. 8. Mustela lutreola. Movement patterns of females with kits in relation to reproductive state. The rectangle indicates the expected time of parturition. F216: 21.05.2006, $15 \mathrm{~d}$ after release (ar); F218: 24.05.2006, $18 \mathrm{~d}$ ar; F370: 24.06.2007, $20 \mathrm{~d}$ ar; F372: 19.06.2007, 29 d ar. Data points not joined by lines indicate that days are missing between data

$(2.3 \mathrm{~km})$. Corresponding with an increase in the mobility of their kits (ca. 7 wk after estimated parturition), home ranges of F216 and F370 increased to $229(4.0 \mathrm{~km})$ and 154 ha $(2.9 \mathrm{~km})$, respectively. The signal of F218 was lost 4 wk after parturition. The movement patterns, displayed as distances from the soft-release pen, showed parallels in behaviour (Fig. 8). Up to 7 wk after parturition no distance change was observed in movement patterns, displayed as distances from the soft-release pen. Monthly change in home range size

Females (F399, F400 and F362) released in August had a maximum home range size of 31 to 2020 ha (1.4 to $7.0 \mathrm{~km}$ ) from September to October. In January, their home ranges shrank to a minimum of 5.9 to 23 ha $(0.4$ to $1.2 \mathrm{~km}$ ) (Fig. 9a-c). Male M223 (Fig. 9d) increased his home range during the observation period from 64.8 ha $(3.6 \mathrm{~km})$ in May to 141.7 ha $(5.6 \mathrm{~km})$ in July. Almost every week, M223 entered river stretches he had not used previously (Fig. 10). Juvenile males (Fig. 9e-g) released in August first occupied new areas and established temporal home ranges of 28 to 297 ha $(1.6$ to $5.1 \mathrm{~km})$ in autumn; in winter these home ranges shrank to minimum sizes of 4.1 to 48 ha (0.4 to $1.6 \mathrm{~km}$ ).

Post-release activity pattern of kits

We calculated the percentage of radiolocations of kits with associated signs of activity ( $\mathrm{N}=408$ radiolocations). Activity (40 to $70 \%$ ) was detected throughout the entire day, with higher levels recorded at night. Of the nocturnal radiolocations, 80 to $100 \%$ were active, especially during dusk (21:00 to $23: 00 \mathrm{~h}$ ) and dawn (3:00 to $4: 00$ h). Very little activity $(20 \%)$ was detected between 13:00 and 14:00 h.

\section{DISCUSSION}

The home range size of male and female European mink differed greatly within the nature reserve 'Täler der ILL und ihre Nebenbäche'. Males used home ranges from 1.7 to $7.2 \mathrm{~km}$ in size, whereas females typically used smaller home ranges $(0.2$ to $5.9 \mathrm{~km}$, although 1 juvenile female used a home range of $9.2 \mathrm{~km}$ ). This corresponds to previously published data (Palazón \& Ruíz-Olmo 1998, Garin et al. 2002a, Macdonald et al. 2002, Fournier et al. 2003).

Sex-specific differences within the home ranges of mustelids seem to be related to their sexual dimorphism; for example, male Mustela nivalis and Mustela erminea use a 2-fold larger home range in comparison to females (King 1975, Erlinge 1977, Macdonald et al. 2004). Studies have shown that male European polecats Mustela putorius and American mink use up to 3 times larger home ranges than females (Gerell 1970, Lodé 1996, Zschille et al. 2006), and male pine martens Martes martes establish larger home ranges (Schröpfer et al. 1997, Zalewski \& Jedrzejewski 2006). Similarly, Somers \& Nel (2004) reported significant differences in home range size of males and females for the African clawless otter Aonyx capensis. In the present study, male European mink home ranges were twice the size those of females, comparable to the results of Palazón \& Ruíz-Olmo (1998) and Macdonald et al. (2002) for Mustela lutreola and to results for Mustela nivalis and Mustela erminea, the smaller members of the Mustelid family (King 1975, Erlinge 1977, Macdonald et al. 2004).

\section{Distribution of sexes}

Results from the present study show that 7 adult females (F216, F218, F271, F272, F370, F399 and F400) and 1 adult male (M223) established home ranges. Further, 1 juvenile female (F362) and 4 juvenile males (M360, M390, M421 and M433) established at least winter home ranges.

Intrasexual overlaps of male home ranges were not found, indicating an exclusivity of territories (Sandell 1989), where less than $10 \%$ overlap is a strong indicator of exclusivity of home ranges.

Following the death of male M223, his home range was partly occupied by the juvenile male M360. These results are consistent with the results of Garin et al. (2002a) and Sidorovich (2000) studying Mustela lutreola populations in the southwestern and eastern part of the species range, respectively, who never observed simultaneous presence of males at the same place. A partial occupation of a home range by a new holder was documented by Garin et al. (2002a). Both intrasex- 

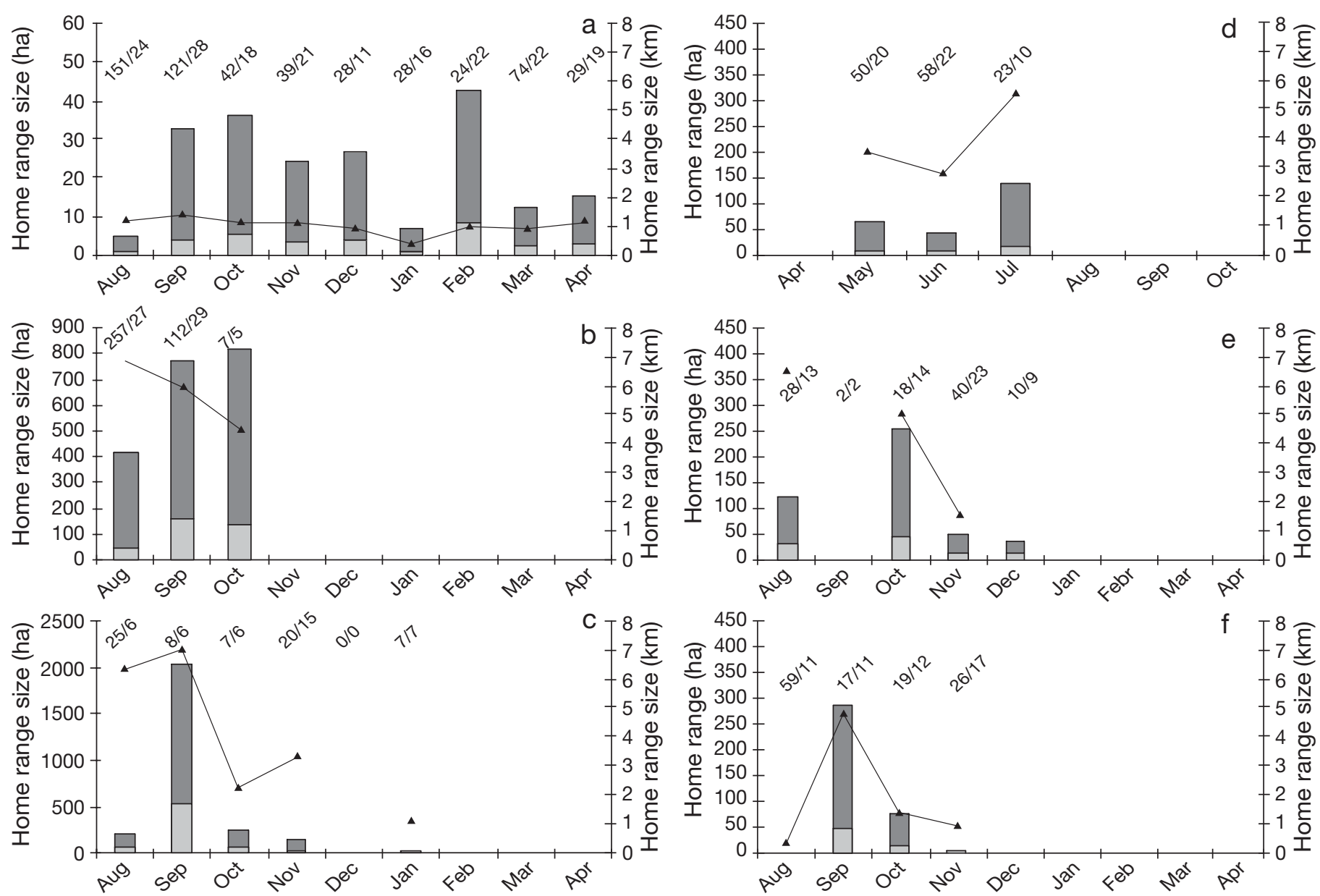

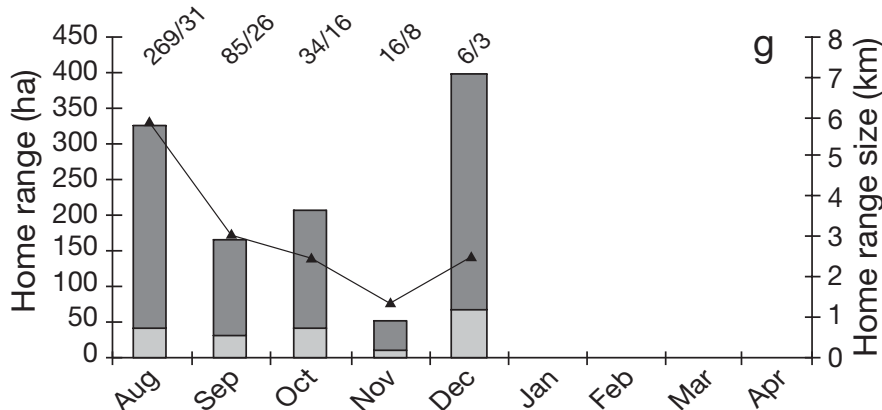

ual exclusivity and the rapid substitution of one adult male by another after the disappearance of the predecessor would imply the existence of a floating population which is pushed by dominant individuals out of main streams into marginal streams, and probably out of aquatic habitats altogether. Thus, European mink populations seem to consist of territorial individuals and floating individuals without a territory (Zuberogoitia \& Zabala 2003). These floaters may disperse, colonizing new areas and connecting otherwise isolated populations (Dunston 1993). The maintenance of exclusive male home ranges may be the best spatial tactic when numbers of females are high and evenly
Fig. 9. Mustela lutreola. Monthly home range size showing 95 and $50 \%$ kernel in ha (dark grey and light grey, respectively), and river length in $\mathrm{km}$ (triangles) of adults: females (a) F399 ( $\mathrm{n}=536)$, (b) F400 ( $=376)$, (c) F362 ( $=67)$ and male (d) M223 ( $\mathrm{n}=132$ ); and juveniles: males (e) M360 (n = 131), (f) M390 ( $\mathrm{n}=121)$ and (g) M421 ( $=410)$. Numbers above bars are number of radiolocations/days surveyed

distributed, so that males can monopolize several females as mating partners (Sandell 1989).

Overlaps between female home ranges occurred only rarely and for short periods. For $5 \mathrm{~d}$ the home ranges of F218, F272 and F271 overlapped. However, F272 and F271 subsequently dispersed and no further overlap with F218's home range was observed, indicating that the latter was able to establish a territory in this area. This behavior supports the intrasexual territoriality hypothesis with indirect evidence on territorial and high quality resource defense. Like F218, both F272 and F271 were pregnant during this period; the lack of home range overlap could be explained by a 


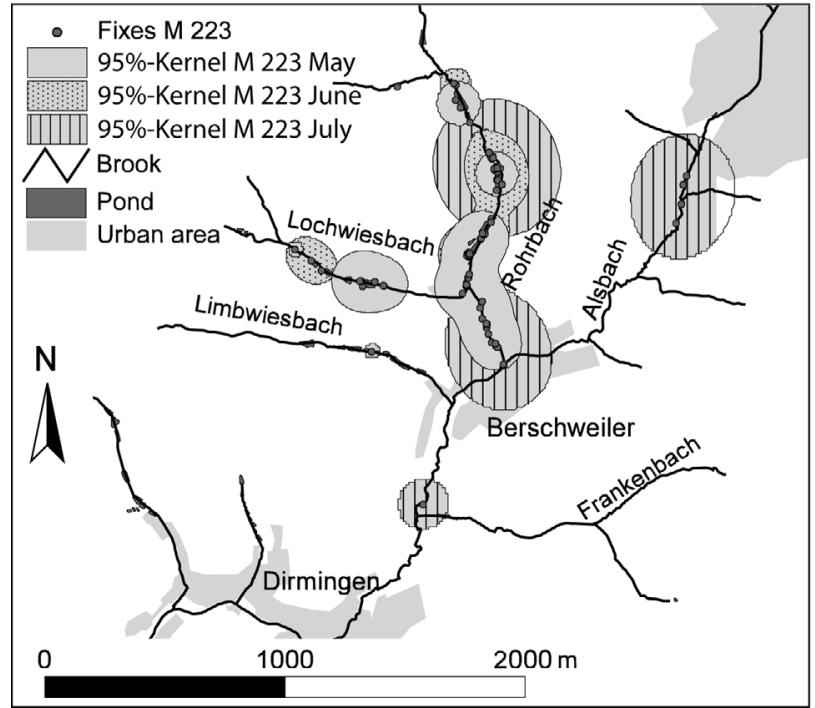

Fig. 10. Mustela lutreola. Monthly enlargement of the home range (95\% kernel) of male M223 ( $=133)$ in 2006

hormone-mediated motivation towards resident behavior, preparation of nest site and exclusion of female conspecifics as competitors. Furthermore, F218 also showed a short-time overlap with the home range of her sister F216. Twelve days after release, F216 left the area to settle in another watercourse $4 \mathrm{~km}$ away from her release site, where she established a permanent home range. Apart from giving evidence of intrasexual territoriality, these observations hint at the intolerance between related females - both of which had even mated with the same male. Agonistic behavior even between related European mink females, especially during pregnancy, was observed previously (Lodé 1996, E. Peters \& B. Habbe unpubl. data).

The observed distribution of females in the present study showed high convergence with other studies of mustelids and wild and reintroduced European mink. Overlaps between territories of female European mink were not documented in previous studies (Palazón \& Ruíz-Olmo 1993, Garin et al. 2002a, Macdonald et al. 2002). Results from the present study thus support the idea of intrasexual territoriality in mustelids, including the European mink (Schröpfer et al. 1997, Johnson et al. 2000).

Intersexual home range overlap even in the nonbreeding season was observed in 3 cases. The home range of male M223 encompassed that of female F218 during the rearing period, suggesting that at least indirect, but probably also direct, contact between male, female and kits occurs. Although such direct contacts have been reported only in semi-natural enclosures, they provide evidence for sociopositive interactions (e.g. social play behavior) between males and their offspring during the rearing period under sufferance by the female. (E. Peters et al. unpubl. data). Thus, we inferred that male M223 accepted the community and social contact with his kits, while frequently investigating his territory and checking on its boundaries. This intersexual overlap during the rearing period supports the protection of the offspring hypothesis (Schröpfer et al. 1997) with the assumption of some paternal care behavior. Unfortunately, male M223 died before the end of the rearing period; thus, in this case we cannot provide evidence for the 'defence of potential mating partner hypothesis' (Johnson et al. 2000). However, in 2 cases, long-term home range overlaps between mothers and their sons were found. In one case a juvenile male remained at the release site together with its mother, while sibling mates emigrated from the release site. In the other case, a juvenile male emigrated together with its mother into a new area. These observations suggest that, at least under the special condition of a recently started reintroduction with naturally low population density, these juvenile males may have: (1) monopolized their mothers as potential mating partners and (2) been accepted in this role by the mothers.

Contrary to these results, the establishment of single home ranges by juvenile males and females was observed after the release of 2 further mother-offspring groups. In one case the mother died shortly after release, in the other case the signal was lost. Thus, no further long-term intersexual home range overlaps were documented, and further research is needed to provide evidence for the defense of potential mating partner hypothesis in the European mink (Johnson et al. 2000). Results further indicate that siblings separate after they have experienced the mother-offspring conflict, since intersexual home range overlaps of male and female siblings released in mother-offspring groups were not observed. These observations suggest that sibling mates do not remain in sibling groups, but migrate solely into new areas to establish their own home range.

In conclusion, the hypothesis that male distribution depends on female occurrence needs to be tested in the future, based on more comprehensive datasets and under conditions of higher population density.

\section{Changes in home range size}

Year-round occupancy of an exclusive home range has been observed in the stone marten Martes foina (Genovesi et al. 1997).

In the present study, at least a 4 mo occupancy of an exclusive home range of male M223 was observed, in which he periodically entered different streams that branched off from the Rohrbach, the main brook used by this animal. Each stream was used for several weeks before switching to another one. Periodic use of 
different regions within a home range has also been observed in the European polecat Mustela putorius and in Mustela lutreola (Weber 1989, Lodé 1993, Garin et al. 2002a), and may be related to exploitation and recovery of food resources.

Juvenile males M360 and M390, released in August, used increasingly larger home ranges across the study period. This is comparable to the large and seasonal home ranges shown by transient, dispersing juveniles of other carnivorous species such as the European polecat, Eurasian river otter Lutra lutra and foxes Vulpus vulpus (Woollard \& Harris 1990, Lodé 1993, Kruuk 1995). A further hint of the existence of a floating population is given by M421 and M433, who established small home ranges within those of their mothers, indicating that these areas were not occupied by a territory holder, so the males could take it over immediately after their male siblings dispersed or died.

Home range sizes of males and females in the present study decreased up until the winter, comparable to the results of Garin et al. (2002a), who showed a decrease in home range size for 1 male from September to February, indicating reduced activity during the winter. Similarly, in enclosures with natural interiors (including water basins, small trees, branches, stones and several hiding places), European mink have shown reduced activity during the winter (E. Peters unpubl. data).

Further, results show that home range size of gestating females decreased with time to parturition. Females in the present study remained sedentary around parturition. After birth and during nesting females typically move their litter to a new den from time to time, allowing access to new hunting grounds and providing the family access to a new latrine area (E. Peters et al. unpubl. data). This can be verified by the present study. Home range sizes of females guiding kits changed during different stages of reproductive state. Females established home ranges which decreased to a minimum prepartum and increased to a maximum at the time of weaning. Movement patterns showed almost no alterations up to $7 \mathrm{wk}$ after parturition, indicating that the release site was suitable for rearing kits, e.g. it provided the necessary food and shelter.

\section{Activity pattern}

In the present study we focused on the activity pattern of Mustela lutreola during the dispersal of the kits. Activity concentrated around midnight and close to dawn. This bimodal activity pattern is comparable to that found in native European mink populations (Palazón \& Ruíz-Olmo 1993, 1998, Sidorovich 1997, Garin et al. 2002b), as well as in other semi-aquatic mustelids such as the American mink (Gerell 1969, Birks \& Linn 1982, Dunston 1993) and the Eurasian river otter (Kruuk 1995). However, M. lutreola, Neovison vison and $M$. putorius showed longer activity periods and higher mobility during the mating season, which is probably related to the search for females. Outside of the mating season, $M$. lutreola presented a lower activity pattern with no distinct nighttime peaks and low crepuscular activity (Garin et al. 2002b). In contrast, the high diurnal activity of the juveniles in autumn may be a strategy to increase the probability of finding suitable habitat with high quality food, e.g. anurans and crabs. An adaptation to the activity pattern of potential prey has been shown in European polecats by Lodé $(1995,1999)$.

Results from the present study demonstrate the ability of released European mink to survive independently. Thirteen animals were able to establish their own home ranges. Intrasexual home range overlaps were not found, indicating an exclusivity of home range. However, intersexual home range overlaps were documented throughout the study period, even during the non-breeding season. Under the special condition of a recent reintroduction program with a naturally low population density, these observations provide the first indications that the distribution of male European mink is dependent on that of females, both for the defense of potential mating partners as well as for protection of offspring, with the assumption of some paternal care behavior. This will be tested in further research based on more comprehensive datasets and under conditions of higher population density

Acknowledgements. We express our gratitude to our partners: W. Festl (EuroNerz e.V.) for practical support and for providing the animals for this project; $H$. Weber for implantation of the transmitters; Zweckverband Illrenaturierung for making the locale available; our volunteers $\mathrm{M}$. Balaguer, $\mathrm{M}$. Bouman, M. J. Borrego Cano, P. Fernandez, S. Gayoso, P. Guitart, S. Grün, M. C. Habba-Carrasco, N. Hermes, S. Hoffmann, J. Jansen, S. Kalbfuss, M. D. Luna-Lemes, J. L. Martinez-Zaporta-Gimeno and N. Wagner for assistance in field work; and their funding organizations ARGO, QUERCUS and FARO (Leonardo da Vinci mobility programs). The reintroduction program was financed by the Ministry of Environment of Saarland (Germany) and Saar Toto, and is part of the federal biodiversity program. Publication was funded by the Zentrale Kommission für Frauenförderung und Gleichstellung of the University of Osnabrueck.

\section{LITERATURE CITED}

Beck BB (1995) Reintroduction, zoos, conservation, and animal welfare. In: Norton BG, Hutchins M, Stevens EF, Maple TL (eds) Ethics on the Ark. Smithsonian Institute Press, Washington, DC p 155-163

Beck BB, Rapaport LG, Stanley Price MR, Wilson AC (1994) Reintroduction of captive-born animals. In: Olney PJS, 
Mace GM, Feistner ATC (eds) Creative conservation: interactive management of wild and captive animals. Chapman \& Hall, London, p 264-386

Birks JDS, Linn IJ (1982) Studies of home range of the feral mink, Mustela vison. Proc Zool Soc Lond 49:231-257

Breitenmoser U, Breitenmoser-Wursten C, Carbyn LN, Funk SM (2001) Assessment of carnivore reintroductions. In: Gittleman JL, Funk SM, Macdonald D, Wayne RK (eds) Carnivore conservation, conservation biology, Vol 5. Cambridge University Press, Cambridge, p 241-281

Broadhurst PA, Sayer J, Nathan AW (1996) Migration of an implantable cardio verter defibrillator generator into the small bowel. Heart 75:368

Dunston N (1993) The mink. T \& AD Poyser, London

Eagle TC, Choromanski-Norris J, Kuechle VB (1984) Implanting radio transmitters in mink and Franklin's ground squirrels. Wildl Soc Bull 12:180-184

Erlinge S (1977) Spacing strategy in stoat Mustela erminea. Oikos 28:32-42

Erlinge S, Sandell M (1986) Seasonal changes in the social organization of male stoats, Mustela erminea: an effect of shifts between two decisive resources. Oikos 47:57-62

Fischer J, Lindenmayer DB (2000) An assessment of the published results of animal relocations. Biol Conserv 96:1-11

Fournier P, Chusseau JP, Dupuch J, Fournier-Chambrillon C, Maizeret C (2001) European mink (Mustela lutreola) and polecat (Mustela putorius) radiotracking: intraperitoneal transmitters as an effective alternative to injuring external equipment. Conference Abstract: International Mustelid Colloquium, 13-16 September 2001, Papenburg, Germany

Fournier P, Maizeret C, Aulagnier S, Chusseau JP and others (2003) Space and habitat use of the European mink ( $M$. lutreola) in the Landes des Gascogne region (France) and preservation guidelines. Conference Abstract: Proc Int Conf Conserv Eur Mink, 5-8 November 2003, Logroño, Spain, p 323

Garin I, Zuberogoitia I, Cabala J, Aihartza J, Clevenger AP, Rallo M (2002a) Home ranges of European mink Mustela lutreola in southwestern Europe. Acta Theriol 47:55-62

> Garin I, Aihartza J, Zuberogoitia I, Zabala J (2002b) Activity pattern of European mink (Mustela lutreola) in southwestern Europe. Z Jagdwiss 48:102-106

Genovesi P, Sinibaldi I, Boitani L (1997) Spacing pattern and territoriality of the stone marten. Can J Zool 75:1966-1971

> Gerell R (1969) Activity patterns of the mink Mustela vison Schreber in southern Sweden. Oikos 20:451-460

> Gerell R (1970) Home ranges and movements of the mink Mustela vison Schreber in southern Sweden. Oikos 21: 160-173

Gough MC, Rushton SP (2000) The application of GIS-modelling to mustelid landscape ecology. Mammal Rev 30: $197-216$

Griffith B, Scott J, Carpenter J, Reed C (1989) Translocation as a species conservation tool: status and strategy. Science 245:477-480

Groombridge B (1994) IUCN Red List of Threatened Animals. IUCN, Gland

Hawkins P (2004) Bio-logging and animal welfare: practical refinements. Mem Natl Inst Polar Res 58(Spec Issue): 58-68

IUCN (1998) Guidelines for re-introductions. Prepared by the IUCN/SSC Re-introduction Specialist Group. IUCN, Gland and Cambridge

Johnson D, Macdonald DW, Dickman A (2000) An analysis and review of models of the sociobiology of the Mustelidae. Mammal Rev 30:171-196
Jule KR, Leaver LA, Lea SEG (2008) The effects of captive experience on reintroduction survival in carnivores: a review and analysis. Biol Conserv 141:355-363

Kenward RE (2001) A manual for wildlife radio tagging. Academic Press, San Diego, CA

King CM (1975) Home range of weasel (Mustela nivalis) in an English woodland. J Anim Ecol 44:639-668

Kreeger TJ, Vargas A, Plumb GE, Thorne ET (1998) Ketamine-medetomidine or isoflurane immobilization of blackfooted ferrets. J Wildl Manag 62:654-662

Kruuk H (1995) Wild otters: predation and population. Oxford University Press, Oxford

Lodé T (1993) Stratégies d'utilisation de l'espace chez le putois européen Mustela putorius L. dans l'ouest de la France. Rev Ecol Terre \& Vie 48:305-322

Lodé T (1995) Activity pattern of polecats Mustela putorius L. in relation to food habits and prey activity. Ethology 100: 295-308

Lodé T (1996) Conspecific tolerance and sexual segregation in European polecat. Acta Theriol 41:171-176

Lodé T (1999) Time budget as related to feeding tactics of European polecat Mustela putorius. Behav Process 47: $11-18$

Macdonald DW (1978) Radio-tracking: some applications and limitations. In: Stonehouse B (ed) Animal marketing. Macmillan Press, London, p 192-204

> Macdonald DW (1983) The ecology of carnivore social behaviour. Nature 301:379-384

Macdonald DW, Sidorovich VE, Maran T, Kruuk H (2002) The Darwin Initiative. European mink, Mustela lutreola: analyses for conservation. Wildlife Conservation Research Unit, Oxford

Macdonald DW, Tew TE, Todd IA (2004) The ecology of weasels (Mustela nivalis) on mixed farmland in southern England. Biologia (Bratisl) 59:235-241

Maran T (2004) Recovery of Mustela lutreola in Estonia: captive and island populations. Project No. LIFE2000NAAT/EE/ 7081, Final Report. www.lutreola.ee/english/LIFEREPORTS_ eng.htm

Maran T, Henttonen H (1995) Why is the European mink (Mustela lutreola) disappearing? A review of the process and hypotheses. Ann Zool Fenn 32:47-54

Maran T, Macdonald DW, Kruuk H, Sidorovich V, Rozhnov VV (1998) The continuing decline of the European mink Mustela lutreola: evidence for the intraguild aggression hypothesis. In: Dunstone N, Gorman ML (eds) Behaviour and ecology of riparian mammals. Cambridge University Press, Cambridge, p 297-324

Mason CF, Macdonald SM (1983) Some factors influencing the distribution of mink (Mustela vison). J Zool 200: 281-283

Michaux JR, Libois R, Davison A, Chevret P, Rosoux R (2004) Is the western population of the European mink, (Mustela lutreola), a distinct management unit for conservation? Biol Conserv 115:357-367

Michaux JR, Hardy OJ, Justy F and others (2005) Conservation genetics and population history of the threatened European mink Mustela lutreola, with an emphasis on the west European population. Mol Ecol 14:2373-2388

Palazón S, Ruíz-Olmo J (1993) Preliminary data on the use of space and activity of the European mink (Mustela lutreola) as revealed by radio-tracking. Small Carn Conserv 8:6-8

Palazón S, Ruíz-Olmo J (1998) A preliminary study of the behaviour of the European mink (Mustela lutreola) in Spain, by means of radiotracking. In: Dunstone N, Gorman ML (eds) Behaviour and ecology of riparian mammals. Cambridge University Press, Cambridge, p 93-105 
Reading RP, Clark TW (1997) Carnivore reintroductions: an interdisciplinary examination. In: Gittleman JL (ed) Carnivore behavior, ecology and evolution, Vol 2. Cornell University Press, Ithaca, NY, p 296-335

Sandell M (1989) The mating tactics and spacing patterns of solitary carnivores In: Gittleman JL (ed) Carnivore behavior, ecology and evolution. Cornell University Press, Ithaca, NY, p 164-182

Schröpfer R (2003) Ein verhaltensbiologischer Ansatz für die Ansiedlung von Säugetieren - Beispiel: Heim-Effekt und Exploration in der Auswilderungsphase bei Biber Castor fiber, Sumpfmaus Microtus oeconomus und Wildnerz Mustela lutreola. Meth feldökol Säugetierforschung 2:359-371

Schröpfer R, Wiegand P, Hogrefe HH (1997) The implication of territoriality for the social system of the European pine marten Martes martes (L., 1758). Z Saugetierkd 62: 209-218

Seddon PJ, Armstrong DP, Maloney RF (2007) Developing the science of reintroduction biology. Conserv Biol 21: 303-312

Sidorovich VE (ed) (1997) Mustelids in Belarus. Evolutionary ecology, demography and interspecific relationships. Zolotoy Uley, Minsk

Sidorovich VE (2000) The ongoing decline of riparian mustelids (Eurpean mink, Mustela lutreola, polecat, Mustela putorius, and stoat, Mustela erminea) in eastern Europe: a review of the results to date and an hypothesis. In: Griffiths HI (ed) Mustelids in a modern world. Management and conservation aspects of small carnivore: human interaction. Backhuys Publishers, Leiden, 295-319

Sidorovich VE (2001) Study on the decline in the European mink Mustela lutreola population in connection with the American mink $M$. vison expansion in Belarus: story of the study, review of the results and research priorities. Säugetierkdl Inf 5:133-153

Sidorovich VE, Savchenko VV, Budny VB (1995) Some data about the European mink Mustela lutreola distribution in the Lovat River Basin in Russia and Belarus: current status and retrospective analysis. Small Carn Conserv 12:14-18

Sidorovich VE, Kruuk H, Macdonald DW (1999) Body size, and interactions between European and American mink (Mustela lutreola and M. vison) in Eastern Europe. J Zool 248:521-527

Skirnisson K, Feddersen D (1984) Erfahrungen mit der

Editorial responsibility: Brendan Godley,

University of Exeter, Cornwall Campus, UK
Implantation von Sendern bei freilebenden Steinmardern. Eur J Wildl Res 30:228-235

Somers MJ, Nel JAJ (2004) Movement patterns and home range of Cape clawless otters (Aonyx capensis), affected by high food density patches. J Zool 262:91-98

Stamps JA, Swaisgood RR (2007) Someplace like home: experience, habitat selection and conservation biology. Appl Anim Behav Sci 102:392-409

Stanley Price MR (1991). A review of mammal reintroductions, and the role of the re-introduction specialist group of the IUCN/SSC. In: Gipps JHW (ed) Beyond captive breeding: re-introducing endangered mammals to the wild. Symp Zool Soc Lond, Vol 62, Clarendon Press, Oxford, p 9-25

Stubbe M (1993) Mustela lutreola (L. 1761): Europäischer Nerz. In: Niethammer J, Krapp F (eds) Handbuch der Säugetiere Europas, Bd. 5, Raubsäuger. Carnivora (Fissipedia), Teil II: Mustelidae 2, Viverridae, Herpestidae, Felidae. AULA, Wiesbaden, p 627-653

Weber D (1989) Foraging in polecats (Mustela putorius L.) of Switzerland: the case of a specialist anuran predator. $\mathrm{Z}$ Saugetierkd 54:377-392

White GC, Garrott A (1990) Analysis of wildlife radio-tracking data, 1st edn. Academic Press, London

Wolf CM, Griffith B, Reed C, Temple S (1996) Avian and mammalian translocations: update and reanalysis of 1987 survey data. Conserv Biol 10:1142-1154

Woollard T, Harris S (1990) A behavioural comparison of dispersing and non-dispersing foxes (Vulpes vulpes) and an evaluation of some dispersal hypotheses. J Anim Ecol 59:709-722

> Zalewski A, Jedrzejewski W (2006) Spatial organisation and dynamics of the pine marten Martes martes population in Białowieza Forest (E Poland) compared with other European woodlands. Ecography 29:31-43

Zschille J, Stier N, Roth M (2006) Zwischenbericht - Untersuchung zu gebietsfremden Raubsäugern-mit Forschungsschwerpunkt Mink. TU Dresden, Institut für Forstbotanik und Forstzoologie

Zschille J, Stier N, Roth M (2008) Radio tagging American mink (Mustela vison): experience with collar and intraperitoneal-implanted transmitters. Eur J Wildl Res 54: 263-268

Zuberogoitia I, Zabala J (2003) Do European mink use only rivers or do they also use other habitats? Small Carn Conserv $28: 7-8$

Submitted: May 15, 2008; Accepted: January 2, 2009 Proofs received from author(s): April 9, 2009 